\title{
Enhancing Core Competencies through Strategic Mergers and Acquisitions and Corporate Venture Capital Investment
}

Corporate venture capital (CVC) and independent venture capital (IVC) differ in their objectives. CVC is more about its own strategic intent and strategic alignment with the parent company, than direct financial returns from the entity receiving investment. In contrast, IVC pursues financial returns; its strategic intent is usually absent or vague.

Trying to achieve both the strategic intent and financial returns presents a dilemma for CVC. Equal emphasis on both usually leads to success in one but failure in the other. If CVC deviates from its strategic intent, it will be no different from IVC. Large companies that expect their CVC initiatives to gain financial returns are putting the cart before the horse.

At Huawei, the strategic intent of CVC is clear: to enhance the core competencies and overall value of the parent company through its strategic and business alignment with the parent company. The goal of CVC is not to solely focus on maximizing the returns of any individual entity that makes investment. Huawei strictly controls the objectives and boundaries of its CVC projects, and prohibits unfocused investment, with the intention of achieving big profits in core business rather than smaller wins across a wider area.

This chapter gives concise and to-the-point explanations about the strategic intent and investment principles of Huawei's CVC. 


\subsection{Bridging Gaps in Core Competencies Through Strategic Mergers and Acquisitions}

\subsubsection{Capital Investment Should Serve the Strategic Purpose and Help Huawei Acquive Key Technologies and Capabilities}

Meeting attendees agreed on a set of capital investment policies which include four key points. First, growing from within is the core and major driving force behind Huawei's future development, whereas capital investment is an alternative that can be used in certain circumstances. Second, capital investment must serve the strategic purpose, which is to help Huawei acquire key technologies and capabilities, or grow market share. Third, mergers and acquisitions (M\&As) must be confined to domains closely related to our core business. Joint venture initiatives may be carried out in domains that slightly deviate from our core business, but must be managed by specific business unit owners. CVC must focus on opportunities that allow us to grow our business ecosystem, stimulate market demand, fill technological gaps, and acquire cutting-edge technologies. Fourth, capital investment is very risky and must thus be treated with caution. Oversight and management are crucial to attaining the objectives of capital investment and reducing associated risks. (Source: Resolution on Proposals for Capital Investment Policies and Decision-making Systems, Finance Committee Resolution No. [2011] 038)

The Corporate Development Department must focus on supporting Huawei's core business. Through capital investment, the department helps business departments rapidly acquire new products and capabilities, address areas of weaknesses, control strategic resources, complement internal innovation, and conduct research through external parties. The department must also actively acquire patents in alignment with Huawei's patent strategy. Capital investment in our core business should be an ongoing effort. (Source: Minutes of the Report on the Results of Operations Management of Capital Investment Projects, EMT Meeting Minutes No. [2014] 001)

\subsubsection{Focusing CVC Investments on Developing Cutting-Edge Technologies, Preventing Technological Risks, and Supporting Development Strategies in Our Core Business}

The Corporate Development Department needs to prioritize and proactively work on technology-related VC. It must do this regularly, with the 
company's future goals in mind and a focus on key technologies for Huawei's core business. (Source: Minutes of the Report on Principal Investment and Venture Capital, Finance Committee Meeting Minutes No. [2012] 046)

CVC is a vital means for Huawei to complement internal innovation, understand and develop cutting-edge technologies, prevent technological risks, and cope with future uncertainties. CVC must be confined to strategic projects that support our core business in ICT and aim to achieve the following goals: create channels for Huawei to access innovation resources and gain insights into innovation trends in the industry; develop cuttingedge technologies and innovate with third parties; control key resources, promote strategic cooperation, and ensure supply security; build a healthy ecosystem for our core business; develop data pipe capabilities, expand pipe traffic, and increase the coverage and volume of connections. (Source: Resolution on Proposals for Optimizing the Venture Capital Decision-making Process and Delegation of Authority, EMT Resolution No. [2015] 006)

The objective of CVC at Huawei is to support the development of our core business. The significance of CVC needs to be clarified, and its boundaries need to be clearly defined. (Source: Minutes of the Discussion on Proposals for Optimizing the Venture Capital Decision-making Process and Delegation of Authority, Finance Committee Meeting Minutes No. [2015] 018)

In principle, we don't invest outside of Huawei. Investing in a company means that we have to buy from them for the rest of our lives. Our approach is this: We buy from whoever provides high-quality products and services. We always look for the best option. We also establish strategic partnerships with our suppliers, but we require that they not lag behind. If they do, we will buy from others. We aim to make the world's best products, rather than just assembling what our partners produce. (Ren Zhengfei: Minutes of a Meeting with Employees of the Japan Representative Office and the Japan Research Center, Huawei Executive Office Speech No. [2016] 080)

\subsubsection{The Purpose of Acquisitions Is to Make Up for Weaknesses in Our Core Business Rather Than Diversifying Our Business}

Since June 2011, the company has stopped investing in non-core business. This ban will remain in force moving forward and all existing investments in non-core businesses will be discontinued. (Source: Minutes of the Report on the Results of Operations Management of Capital Investment Projects, EMT Meeting Minutes No. [2014] 001) 
As our future direction indicates, our strategic goal is all about vertical development in our data pipe business, instead of horizontal expansion. The amount that we invest in the data pipe business is higher than any other company. It is a well-known fact that every year we invest about 8 billion US dollars in R\&D, and we can do this without any difficulty. Our capital structure supports this investment strategy, without the need for new capital from outside investors. Huawei is not likely to become an investment company that answers to investors. Huawei answers only to employees who have put their own efforts into the company. (Ren Zhengfei: Speech at a Meeting with Employees of the Legal Affairs Department, Secretariat Office of the Board of Directors, and Wireless Network Product Line, Huawei Executive Office Speech No. [2015] 015)

Huawei sticks to its core business. All acquisitions aim to make up for weaknesses in our data pipe business, not to diversify our business. Huawei has never ceased acquisition efforts. Acquisitions valued below 10 million US dollars don't need my approval, so the number of our acquisition projects should not be insignificant. At Huawei, the purpose of acquisitions is to make up for what we lack in our data pipe business, not to further diversify our business. If we acquire a ton of companies doing other businesses, what if they're just shells? Or what if they're poorly run? Such companies will only hasten our demise. The most profitable business in the world is printing money. But this isn't practical, so we need to be selective about what we do and what we don't do. (Ren Zhengfei: Speech at a Meeting with Employees of the Legal Affairs Department, Secretariat Office of the Board of Directors, and Wireless Network Product Line, Huawei Executive Office Speech No. [2015] 015)

\subsection{Principles For External InVESTMEnts AND M\&As}

\subsubsection{Never Making Principal Investments Aimed Solely at Achieving Financial Returns}

The company reaffirms the prohibition of principal investments that only seek financial returns. (Source: Minutes of the Report on Principal Investment and Venture Capital, Finance Committee Meeting Minutes No. [2012] 046)

Moving forward, all investments, mergers, and acquisitions must be centrally managed and reported by the Corporate Development Department to company management. This department must ensure the 
scope of our investment remains focused on our core business. Projects that are not included in the project pipeline of the department are "illegal", and will not have the support or approval of the company. Over the next two years, our company will strengthen the management of these projects and keep a tight rein on M\&A-driven business development. (Source: Recommendations on Investment and M\&A Management, EMT Resolution No. [2011] 041)

When there is a new project request, the Corporate Development Department must carefully assess whether it falls within the scope of our core business. When assessing investments and doing project initiation verification, the department must approach its work in an objective, neutral, and professional manner. The goal is to ensure the quality of the project from the very beginning. (Source: Minutes of the Report on the Results of Operations Management of Capital Investment Projects, EMT Meeting Minutes No. [2014] 001)

\subsubsection{Strengthening Post-Investment Management to Ensure Investment Goals Are Achieved}

Expenses on capital investment projects, including investment funds, M\&A funds, and project operating costs, must be borne by the departments that benefit from such projects. According to this principle, the investments or M\&A funds for these projects need to be budgeted and accounted for under the "investment centers" (such as BGs and product lines), rather than under the "non-investment centers" (such as regional offices, representative offices, or key account departments). (Source: Regulations on Budgeting and Accounting of Expenses on Capital Investment Projects, Finance Committee Doc. No. [2012] 001)

The Corporate Development Department needs to strengthen postinvestment integration and management to ensure investment goals are achieved. Incubating a potential investment project and managing it in the post-investment stage are crucial tasks for this department. (Source: Minutes of the Report on the Results of Operations Management of Capital Investment Projects, EMT Meeting Minutes No. [2014] 001)

\subsubsection{No Support for Employees Starting a Business: No Investing or Engaging in Such Activities}

The cost of any failed investment must be borne by the organization that made the decision to invest. Huawei forbids the sale of any business to 
external parties. If a business losses momentum or does not align with the company's strategic demand, it must be directly closed, rather than sold. Huawei does not support employees starting a business; nor does it invest or engage in these activities itself. (Source: Resolution on Forbidding Internal Start-ups and Sale of Any Business, EMT Resolution No. [2015] 012)

Open Access This chapter is licensed under the terms of the Creative Commons Attribution-NonCommercial-NoDerivatives 4.0 International License (http:// creativecommons.org/licenses/by-nc-nd/4.0/), which permits any noncommercial use, sharing, distribution and reproduction in any medium or format, as long as you give appropriate credit to the original author(s) and the source, provide a link to the Creative Commons licence and indicate if you modified the licensed material. You do not have permission under this license to share adapted material derived from this chapter or parts of it.

The images or other third party material in this chapter are included in the chapter's Creative Commons licence, unless indicated otherwise in a credit line to the material. If material is not included in the chapter's Creative Commons licence and your intended use is not permitted by statutory regulation or exceeds the permitted use, you will need to obtain permission directly from the copyright holder. 